\title{
Duties and Powers of The Department of Public Works and Spatial Planning in The Implementation of Road in Kendal
}

\begin{abstract}
Nabella Maharani Novanta ${ }^{1}$
Abstract. This study discusses the role of the Department of Public Works and Spatial Planning in the implementation of the road in Kendal. Here is more towards the implementation of the supervision. Research problems concerning form of oversight, relations with relevant institutions, as well as the obstacles faced by the Department of Public Works and Spatial in Kendal. To answer these problems required legal research activities, using empirical juridical approach. Sources of data obtained through interviews with sources as well as legislation, legal theory, and the opinions of the leading scholars as support material, and then analyze it in order to get an answer scientifically.

Keywords: Local Government; Roads Implementation; Monitoring.
\end{abstract}

\section{Introduction}

Road as one of the transport infrastructure is the lifeblood of the community. He has an important role in efforts to develop the nation and state. The road also has a major role to support economic activity, social, cultural, environmental, political, defense and security. Therefore, to build a road in order to meet the requirements as a means of transportation of goods and services that are safe, convenient, and useful really would benefit the community. ${ }^{2}$

Formeet the needs of the community, develop a road can be done through the development of the region. This approach aims to achieve balanced and equitable development between regions, establish and strengthen national unity, strengthen national defense and security, as well as the structuring of space in order to achieve national development goals. ${ }^{3}$

Regulation in Kendal area No. 10 of 2015 concerning Road in Article 1 (7) states that the implementation of the road is an activity that involves setting, coaching, development, and supervision of the road. Implementation of the road included in government affairs relating to basic services in the field of public works and arrangement of space as defined by Act No. 23 of 2014 on Regional Government. The regional government shall provide a good road network system and excellent quality of roads, both in the design and ongoing maintenance. Therefore, the Regional Government needs to monitor either of the setting, coaching, as well as road construction.

The law indicated fully that local governments are required to provide a good road network system and excellent quality of roads, both in the design and ongoing maintenance. This can be done when followed by the regular supervision. Supervision aims to realize the orderly organization of the road. Control can be carried out by

\footnotetext{
${ }^{1}$ Student of Master of Law Diponegoro University Semarang maharaninabella@gmail.com

2 Kansil C.S.T Engelien Palandeng dan Altje Agustin Musa Tindak Pidana dalam Undang-Undang Nasional (Jakarta: Jala Permata Aksara 2009) p.180.

${ }^{3}$ Iskandar Hikmat. "Standar Jalan yang Berwawasan Keselamatan Transportasi Darat" de
} 
parties appointed to perform supervisory duties of the road. Likewise with the supervision of the district conducted by authorized agencies in the local area. In Kendal, state road surveillance conducted by the Department of Public Works and Highways Spatial Planning field.

But of the importance of the function of the road, still a lot of damage to the road. Disturbingly that any damage was not immediately get improved, so that damage to the threshold endangering road users. As a result of damage to the roadway, the community is also involved in the accident or loss associated with a condition like roads. Cases involving road damage following components: first, the traffic conditions; where necessary adequate controls on vehicles passing through a road section, as shown in the case of overload (overloading). Second, management of space around the street; without control of development around the road, the road infrastructure is very susceptible to damage. Third, the management of the activities in the surrounding streets;

Condition road in Kendal as one of the areas traversed as Pantura can not avoid the damage to the road. Such damage is not only the province but also damage to the road district roads. It can be seen from the condition and status of roads in Kendal district as follows: ${ }^{4}$

Table 1 Kendal Road Condition

\begin{tabular}{|l|c|c|c|c|c|}
\hline \multirow{2}{*}{ Road condition } & \multicolumn{5}{|c|}{ Status of District Street / Kendal City } \\
\cline { 2 - 6 } & 2013 & 2014 & 2015 & 2016 & 2017 \\
\hline Good & 240949 & 245120 & 286035 & 338011 & 357768 \\
\hline Moderate & 150296 & 183250 & 172580 & 150016 & 146320 \\
\hline Broken & 149698 & 209608 & 197177 & 167787 & 133930 \\
\hline $\begin{array}{l}\text { Heavy } \\
\text { Damage }\end{array}$ & 230050 & 133015 & 115201 & 115179 & 132975 \\
\hline \multicolumn{1}{|c|}{ Amount } & 770993 & 770993 & 770993 & 770993 & 770993 \\
\hline
\end{tabular}

The condition of roads damaged in Kendal at the end of 2017 along the 133930 kilometers or 17.37 per cent, while the way in severely damaged condition 132975 or 17.24 percent. This shows that 34.61 percent of the total yan district roads damaged and must get the attention of government Kendal. Seeing the condition of the road is so, of course have an impact not only economically but also socially. From an economic perspective, inadequate road infrastructure that would impede the course of the traffic of goods and people. These conditions attract researchers to conduct research on the role and authority of the Department of Public Works and Spatial Planning in the implementation of the road in Kendal.

The research proves that the surveillance as a form of control over the activities of government on the issue of infrastructure facilities. Monitoring basically done by several stages, namely preparation phase, the implementation phase and reporting

\footnotetext{
${ }^{4}$ Rekapitulation of damage data of road in the district of Kendal in 2016-2017
} 
phase. Recognized in the regulatory process is still less than optimal, yet their determination regularly scheduled surveillance activities. Supervision is done only at the time after a report from the road users, mass media or any public figure. ${ }^{5}$

Mockler ${ }^{6}$ suggest in supervising achieve optimum results, emphasize on four issues, namely: (1) must plan, standards or goals as benchmarks to be achieved, (2) the process of implementation of the work to achieve the desired goal, (3) the business compared to what has been achieved under the plan, standards or goals that have been set, (4) take corrective action as necessary.

Supervision of the road which is the object of this study refers to the theory of supervision by Sujamto. That's because the sense given by Sujamto appropriate to complete this study. According Sujamto, surveillance was conducted to compare the results in reality with the desired result. Due to the implementation at the field many obstacles so that the end result is sometimes not as expected. ${ }^{7}$

This study aims to investigate the, (1) the form of supervision street conducted by the Department of Public Works and Spatial Planning, (2) the relationship of the Department of Public Works and Spatial with relevant agencies in supervising the way in Kendal district, and (3) the constraints Works Department general and Spatial Planning in overseeing the way in Kendal district.

Types of qualitative research using empirical juridical approach. Application of the method with the objective to compare das das sein sollen and supervision in the existing road. This is to answer whether the surveillance carried out by the agency in the field are in accordance with the laws and regulations that exist. This study is specified as an analytical descriptive study, the research describes in full on the nature, circumstances, the behavior of individuals or groups as well as the symptoms based on the facts as they are. ${ }^{8}$

While the descriptive analytical research seeks said the existing problem-solving based on the data, so it also presents the data, analyze, and interpret. Source data using primary data material in the form of interviews with persons, namely the head of Highways Department of Public Works and Spatial Kendal. Secondary materials from materials that shed light on the primary legal materials. ${ }^{9}$ As for the secondary material is composed of legislation and literature related to roads and local government oversight. As for the tertiary material in the form of legal dictionaries, encyclopedias Indonesia, etc. All data that has been collected from the study of literature and then processed and analyzed using qualitative methods. This method focuses on the general principles underlying the embodiment of the units of the symptoms that exist in people's lives. ${ }^{10}$

\footnotetext{
${ }^{5}$ Ulvi Fandri Pengawasan Pemeliharaan Jalan oleh Bidang Bina Marga Dinas Pekerjaan Umum Kota Tanjungpinang Publication Manuscript Studies Program of Public Administration Faculty of Social and Political Sciences University of Maritime Raja Ali Haji Tanjungpinang 2016.

${ }^{6}$ Samuel C. Certo dan Travis Certo Modern Management (Pearson Prentice Hall 2006) p. 480.

${ }^{7}$ Sujamto Aspek-Aspek Pengawasan di Indonesia (Jakarta : Sinar Grafika 1987) p.53.

8 Ibid p. 32.

${ }^{9}$ Bambang Sunggono Metodologi Penelitian Hukum (Jakarta : Rajawali Pers 2010 p. 114.

${ }^{10}$ Ibid p. 21.
} 


\section{Results and Discussion}

\subsection{The shape of the surveillance conducted by the Department of Public Works and Spatial Planning}

Kendal district government through the Department of Public Works and Spatial Planning, seeks to provide satisfactory services for society. One form of such services provide transportation in the form of road. Building and repairing roads it a job that requires planning, implementation, and significant funding. To maintain existing roads and the continuity of the function as the designation, either the district or the village road needed supervision.

Monitoring conducted by the Department of Public Works and Spatial Planning, using the guidelines Regulation of the Minister of Public Works No. 04 / PRT / M / 2012 on Procedures for Monitoring and Evaluation Activity Street include Assessment Policy Implementation Implementation of the Road. This activity consists of; (A) evaluation and assessment of road system, including road network system settings according to road function and road status. Setting road network system according to the function of the road and the road status includes document the procedure of preparation, setting process, and the road network system, (b) the evaluation and assessment of the programming system, includes programming system road handling that consists of the procedure of preparation, determination, and document management program road , (c) the evaluation and assessment of the budgeting system,

The interview with the Head of Highways Department of Public Works and Spatial Kendal district, other forms of surveillance is surveillance documents and site supervision. This statement refers to Ministry of Public Works No. 04 / PRT / M / 2012 on Procedures for Supervision of Road Section 4, paragraph (1) shall be at least 1 (one) time in 1 (one) year and is done through the control of documents and site supervision.

Supervision Evaluation and Assessment document Implementation Policy Implementation Road. Evaluation and Assessment consists of documents which include; (A) determining the road network system, covering document setting process and the determination of the road network system. This document examination carried out by assessing the suitability of the criteria set forth in the Form A.1 in the appendix, (b) an assessment of the programming system includes the programming process documents and document handling road. This document examination carried out by assessing the suitability of the criteria set forth in the Form A.1 in the appendix, (c) an assessment of the budgetary system, covering budgeting documents and the budget approval process road handling. This document examination carried out by assessing the suitability of the criteria set forth in the Form A.1 in the annex, (d) road construction standards, including technical planning documents and the implementation of road. Examination of documents associated with the construction standards include compliance with the technical planning of the document / technical planning activities as contained in the Form A. 2 in the appendix. While the standard of the examination of documents related to the implementation of the road construction includes the fulfillment of the document set forth in the Form A.3 in the annex, and (e) the management of maintenance and operation of roads, including the planning and 
implementation document maintenance, and operation of the street. Examination of the planning documents and the implementation of road maintenance include compliance with road maintenance technical documents as stated on Form A.4 in the annex. Whereas examination of the operation document include compliance with the operation of the technical documents as stated on Form A.5 in the annex.

Inspection of documents include the examination of the implementation of performance evaluation documents, as well as document control functions and benefits of development. Inspection document road management performance evaluation is done through the examination of Government Performance Accountability Report hereinafter abbreviated LAKIP. LAKIP document examination conducted by assessing the suitability of the criteria set forth in the Form B.1 in the appendix. While the inspection document control functions and benefits of the results include the construction of roads, driveways control document examination, examination of the benefits of space surveillance documents to keep functioning; and examination of documents prevention of malfunctioning of the road.

Field inspections carried out on district / city roads and rural roads include, (a) conformity document the performance of the implementation of policy for carrying out the road to implementation in the field, (b) the examination of conformity document the performance of control functions and benefits of the results of road construction by conditions on the ground, and (c) examination of documents conformity with the minimum service standards for street performance. Supervision of district / city roads, and rural roads include performance evaluation of the implementation of the Road. The performance evaluation of road management includes setting performance evaluation, coaching, supervision, and development. Setting performance evaluation, coaching, supervision, and construction of the road include the establishment of performance plans, performance measurement, performance analysis and performance reporting arrangements, supervision, monitoring,

Supervision of district roads under the authority of the Regent. Regent Department of Public Works and Spatial hereinafter abbreviated PUPR Department. Supervision is done by the county road Maintenance Section Roads and Bridges Division of Highways. Supervision of the road should be done by the regulatory body, but because of limited human resources and budget in Kendal, then the watchdog road t can not be formed. Currently ongoing road construction, road surveillance supervisor assisted by consultants from the contractor under the contract approved. However, when the implementation of the development has been completed, control entirely the responsibility of the Department of PUPR assisted by UPTD (Office of Technical Implementation Unit). Kendal PUPR UPTD Department consists of 5 areas: (1) Region I, consisting of the District Kendal, Pegandon,

\subsection{Relations Department of Public Works and Spatial Planning with relevant agencies in supervising the way in Kendal district}

Implementation of the road by the Department PUPR supervision is to run more optimally would require cooperation with other agencies. Transport Department, the Police, the Regional Disaster Management Agency (BPBD). 


\subsubsection{Department of Transportation}

Department of Transportation is responsible for road signs and tonnage (payload) of motor vehicles. Because the cause of the destruction of the district roads one of which is transport-freight load payload that is too heavy and did not comply with the rules (the class). Road damage occurs faster because the road burdened beyond its capacity. Tolerance amount allowable load is still $50 \%-60 \%$; means the planned path for single axle load of 8 tons to 10 tons are still permitted to pass a truck with 16 tons of single axis. With these tolerances, of road damage occurs 6.5 times faster.

Implementation of the monitoring system uses two kinds of systems are stationary system by conducting checkpoints at every location of the bridges in the district Kendal by pemantauaan, custody and arrangements for the implementation of orderly traffic running smoothly. Stationary surveillance is done by analyzing and estimates of strategic locations for holding checkpoints. Based on the analysis and the forecasts can be seen fixing locations where it would be made checkpoints that make it easier for inspectors to carry out supervision.

Selanjutnnya mobile system is to conduct roving patrols using either the 4-wheel vehicles and motorcycles 2 and do pemantauaan, custody and arrangements In order to ensure orderly traffic safely and smoothly and there are no more violations. Monitoring carried out by the officers of this mobile system to patrol and monitor the traffic situation in the area of his patrol if there are issues that arise on the street such as traffic, traffic violations and accidents, the inspectors descended directly take action, setting and maintenance. Usually done regular assessments that within six months, wherein in performing the tasks rated as the results when they are in accordance with the performance standards operasionalnnya or not and the results of those assessments to evaluate the performance of the field surveillance officers. In case of violations by the officers in carrying out their duties, there will be action either verbal warning, written, as well as sanctions against karirnnya or his survival.

\subsubsection{Police}

Police help in terms of providing an appeal. The police usually provide information in the event of accidents caused by damage to the road, then the Department of PUPR accommodate the information to determine the next steps. But before the Office PUPR should also consider whether the damaged roads included in their responsibility or not.

Regarding the duty of the police in law enforcement, Barda Nawawi Arif said that there were two police duties in the field of law enforcement, the rule of law in judicial penal which focuses on the repressive nature and enforcement by means of a non-penal that focuses on nature preventive. Law enforcement against the organizers of the road police unit laka use three things are preentif, preventive and repressive. ${ }^{11}$

Law enforcement preentif an initial actions carried out by the police for as early in preventive measures in the offense. Such actions include dissemination and outreach to the community, especially in terms of prevention of accidents due to road damage. Namely a preventive law enforcement to prevent crimes and violations by focusing

\footnotetext{
${ }^{11}$ Kelik Pramudya dan Ananto Widiatmoko Pedoman Etika Profesi Aparat Penegak Hukum (Jakarta: Pustaka Yustisia 2006) p. 113'
} 
factor of chance, in this respect there is a presumption that a crime or a violation would occur if the intention of factors met by a factor of chance. In terms of law enforcement in order to run in accordance with properly, then the application must be contained legal principles in order to ensure justice for all levels of society.

Preventive measures that have been committed by the police, among others, integrated survey of damaged roads in collaboration with the organizers of the street and the Department of Transportation, the posts remain to overcome if there is an accident with a quick, routine patrols and joint patrols daily and intensive patrolling of areas prone to accidents and traffic jams the last act is repressive, that is real enforcement action against the violations that have been held by commitee of road building. Repression is repression to date have not been implemented because of the bad roads is not a dominant factor of the traffic accident occurred.

The dominant factor is the police according to the man himself, although at the time of absolute accident damaged due to road conditions. Usually there is a meeting conducted by the Police Offices and discussing the road called meetings of the national road. The meeting is not a meeting that is routinely done, but only at Certain times, such as when going widths. At the meeting the Department PUPR usually only provide information about any way damaged and needs improvement before Reviews their homecoming, Because The national road is not the responsibility of the Department of PUPR.

\subsubsection{Regional Disaster Management Agency (BPBD)}

Regional Disaster Management Agency or hereafter known as BPBDs usually help in the repair of existing roads in emergencies / had a direct impact to the community. But do BPBDs handling is only temporary, while the handling of permanently fixed from the Department PUPR. In this case BPBDs directly facing Regents for approval to repair the road. And from the Department PUPR duty to advise what steps should be done by BPBDs.

\subsection{Barriers Department of Public Works and Spatial Planning in overseeing the way in Kendal}

PUPR Office in carrying out supervisory duties of the road course encountered some resistance from both internal and external. External barriers include; $(A)$ lack of public awareness. Public awareness during this time to keep the infrastructure in the region is still considered low, for example, people still often brought water illegally. In fact it is clearly prohibited and can damage the facilities that have been made by the government. As a result of these actions, besides damaging the facility that has been built by local governments, but also broad impact to other road users (b) Excess tonnage of Transportation. It is often a major obstacle for the government in implementing the monitoring and maintenance of roads. Excess tonnage which is often carried by cargo trucks that are in progress these projects often disturbing both from public and road users. For the government, the excess tonnage can shorten the life of the road and of course it will increase the program of work should be done by the government. Truckloads of excess highly effect on the damaged road. The road damage is proportional to the percentage of overweight compared with a charge of 
appropriate amount of load permits (JBI). Truckloads of excess reached $50 \%$ affect road maintenance costs of up to 2.5 times the planned routine maintenance costs per year within the period of service life. Road damage caused by overloaded truck with a $50 \%$ increase transportation cost of $\mathrm{Rp} .45$ ton $/ \mathrm{km},{ }^{12}$ Damage to roads lead to high economic costs, because the travel time is longer and the vehicles are also more easily damaged. If overloading should be demoted or fined, then the excess fines should be used as compensation for the rehabilitation of damaged roads, because overloading resulting in damage to roads and dangerous for the safety and comfort of road users, (c) Lack of coordination of agencies-Associated Institutions. Fellow related agencies responsible for both physical way, building on a side street and road markings are still working individually. Lack of coordination is certainly hamper the regulatory process. Internal barriers include; (A) the limited number of human resources. Related to the amount of human resources is one of the internal resistance of the Department PUPR. The number of staff at the Department PUPR are limited and must take care of the affairs of not only the roads, but also on irrigation, copyrighted works and layout. Affairs of the road is also not just monitoring the road, but also concern about road planning, road construction and road maintenance, (b) the low number of budgets. It is also one of the obstacles in the implementation of the supervision. Budgets are owned by local governments and to local governments from the central government is not only addressed to the Office of PUPR alone, but must also be shared with other agencies with appropriate work program priorities. Often the amount of budget received by the department is a smaller number than the budget that has been prepared in the work program. So from the department itself should determine the priorities of the work program itself.

\section{Closing}

\subsection{Conclusion}

Result analysis and discussion on the role and authority of the Department of Public Works and Spatial Planning in the implementation of the road in Kendal, can be summed up as follows:

- Monitoring conducted by the Department of Public Works and Spatial Planning, using the guidelines Regulation of the Minister of Public Works \# 04 / PRT / M / 2012 on Procedures for Monitoring Road. The forms of supervision items, namely the control of documents and site supervision. The shape of this oversight accordance with the Regulation of the Minister of Public Works \# 04 / PRT / M / 2012 on Procedures for Supervision of Road Section 4, paragraph (1) shall be at least 1 (one) time in 1 (one) year and is done through the control of documents and site supervision,

- Relations Department of Public Works and Spatial with relevant agencies in supervising the way in Kendal district. (A) the relationship with the transportation bureau associated with road signs and tonnage (payload) of motor vehicles. Because the cause of the destruction of the district roads one of which is transport-

\footnotetext{
${ }^{12}$ Sofyan M. Saleh dkk Pengaruh Muatan Truk Berlebih terhadap Biaya Pemeliharaan Jalan Jurnal Transportasi Vol. 9 No. 1 June 2009 p. 79-89.
} 
freight load payload that is too heavy and did not comply with the rules (the class). Road damage occurs faster because the road burdened beyond its capacity, (b) the relationship with the police, the police usually provide information in the event of accidents caused by damage to the road, then the Department of PUPR accommodate the information to determine the next steps. But before the Office PUPR should also consider whether the damaged road is included in its responsibilities or not, and (c) the relationship with the Regional Disaster Management Agency or hereafter known as BPBDs usually help in the repair of existing roads in emergencies / had a direct impact to the community. But do BPBDs handling is only temporary, while the handling of permanently fixed from the Department PUPR. In this case BPBDs directly facing Regents for approval to repair the road. And from the Department PUPR duty to advise what steps should be done by BPBDs. But do BPBDs handling is only temporary, while the handling of permanently fixed from the Department PUPR. In this case BPBDs directly facing Regents for approval to repair the road. And from the Department PUPR duty to advise what steps should be done by BPBDs. But do BPBDs handling is only temporary, while the handling of permanently fixed from the Department PUPR. In this case BPBDs directly facing Regents for approval to repair the road. And from the Department PUPR duty to advise what steps should be done by BPBDs.

- Barriers Department of Public Works and Spatial Planning in overseeing the way in Kendal, namely internal and external obstacles. Internal barriers include; the limited number of human resources, the low number of budgets. External barriers include; low public awareness, excess tonnage of Transportation, and the lack of coordination of the agency-Related Agencies.

\subsection{Suggestion}

The suggestions can be disampikan related to the duties and authority of the Department of Public Works and Spatial Planning in the implementation of the road in Kendal, including:

- To ensure the effectiveness of supervision should be done by those who are competent, according to regulations. This is not only done by a third pinghak, but is done by the local UPTD UPTD-periodic and planned.

- The synergy between the relevant agencies in order to optimize the benefits of its designation, can be programmed coordination. It can be initiated and spearheaded by the Department of Public Works and Spatial Planning.

- To reduce barriers have limited amount of the budget can be allocated on Budgets Work Plan prepared at the beginning of the year based on a proper analysis of the results of field inspections and documents, recruit qualified resources or apply force to the Personnel Board of Education and Training Kendal.

\section{References}

[1] Bambang Sunggono 2010 Metodologi Penelitian Hukum Jakarta: Rajawali Pers.

[2] Kansil C.S.T Engelien Palandeng dan Altje Agustin Musa 2009 Tindak Pidana dalam Undang-Undang Nasional Jakarta: Jala Permata Aksara 
[3] Kelik Pramudya dan Ananto Widiatmoko 2006 Pedoman Etika Profesi Aparat Penegak Hukum Jakarta: Pustaka Yustisia

[4] Sofyan M. Saleh dkk Pengaruh Muatan Truk Berlebih terhadap Biaya Pemeliharaan Jalan Jurnal Transportasi Vol. 9 No. 1 June 2009.

[5] Samuel C. Certo and Travis Certo 2006 Modern Management Pearson Prentice Hall

[6] Sujamto 1987 Aspek-Aspek Pengawasan di Indonesia Jakarta: Sinar Grafika.

[7] Ulvi Fandri 2016 Pengawasan Pemeliharaan Jalan oleh Bidang Bina Marga Dinas Pekerjaan Umum Kota Tanjungpinang Publication Manuscript Studies Program of Public Administration Faculty of Social and Political Sciences University of Maritime Raja Ali Haji Tanjungpinang.

[8] Iskandar Hikmat. "Standar Jalan yang Berwawasan Keselamatan Transportasi Darat" http://118.97.186.88//upload/jurnal/2008/JN2501APR0801.pdf. accessed on March 1, 2018. 